\title{
ASYMMETRIC TAXATION AND CROSS-BORDER INVESTMENT DECISIONS
}

\author{
RAINER NIEMANN
}

\author{
CESIFO Working PAPER No. 1219 \\ CATEgORY 1: Public FinANCE \\ JUNE 2004
}




\title{
Asymmetric Taxation and Cross-Border Investment Decisions
}

\begin{abstract}
This paper analyzes the impact of particular loss offset limitations on intrastate and crossborder investment decisions. Investment can be realized in the investor's domestic business, in a foreign branch or in a foreign subsidiary. The relative impact on the optimal real investment alternative compared to the optimal financial investment alternative indicates the investment incentives of tax law asymmetries. Integrating an initial loss carryforward at the time of investment creates a special decision situation. Varying loss offset parameters typically induces ambiguous effects that depend on the combination of all parameters under consideration. On average, a domestic minimum tax and a time limit on loss carryforwards tend to depress real investment. However, it is possible to find counter-examples. Real investment projects with decreasing cash flows and expected infra-marginal projects are less likely to be discriminated against than projects with increasing cash flows and expected marginal projects, respectively. An initial loss carryforward generates a domestic lock-in effect that may be intensified by loss offset limitations. Depending on the parameter setting, the opposite - a push-out effect - may occur as well.
\end{abstract}

Keywords: investment, asymmetric taxation, loss offset, loss carryforward, minimum tax.

JEL classification: H25, G31.

Rainer Niemann

University of Magdeburg

Department of Economics

P.O.Box 4120

39019 Magdeburg

Germany

rainer.niemann@ww.uni-magdeburg.de 


\section{Introduction}

Tax planning of cross-border investment is a quite demanding task. Investors have to take the multitude of national tax systems as well as their interdependencies into account. Compared to intrastate investment decisions, the number of variables and restrictions rises dramatically. This is obvious even when deciding upon whether or not to carry out a single real investment project. Assuming a given legal structure, it is sufficient to evaluate the objective variables, e.g. post-tax net present values (NPVs) or future values $(\mathrm{FVs})$ for deciding on domestic investment. Adding the possibility of cross-border investment, it becomes necessary to optimize the legal structure of foreign activities because this determines whether a double taxation occurs and which method can be applied to avoid double taxation. In the following step, the value of the objective function for realizing the project can be compared to the value of the objective function for the alternative financial investment that might be realized instead. Optimization of the legal structure of foreign activities is necessary not only for the project under consideration, but also for financial investment, because appraisal of a particular investment project must refer to the optimal alternative, not an arbitrary one. Thus, cross-border investment involves at least a two-stage optimization process.

Tax loss offset rules are crucial parameters for both intrastate or cross-border tax planning. Asymmetric taxation, i.e. deviations from the neutral case of immediate and full loss offset are applied in nearly any country. Internationally, there is a wide variety of different loss offset limitations which cause additional tax planning and tax compliance costs.

Asymmetric taxation typically reduces an investor's wealth, whereas the investment incentives are ambiguous, at least for domestic investment ${ }^{1}$. In contrast, it is not yet clear which investment effects are caused by a minimum tax or other types of loss offset limitations in an international context. A thorough analysis has to take tax effects on each investment alternative into account, this means real as well as financial investment. This is especially true for cross-border decisions where tax loss offset rules determine the legal structure of different alternatives. The objective of this paper is to quantify the resulting investment incentives.

Variations of the loss offset parameters will be analyzed with regard to the following questions:

- Which is the optimal legal structure for real and financial investment?

- Is domestic or foreign investment taxed preferentially?

- Is real or financial investment taxed preferentially?

\footnotetext{
${ }^{1}$ Cf. Niemann (2003).
} 
- Which legal structure of foreign investment is taxed preferentially?

The question of a possible tax loss offset paradox deserves special attention. This means that either real investment compared to financial investment or domestic investment compared to foreign investment is encouraged due to restricting domestic loss offset rules. The basis for this analysis is an individual investment model that yields not only individual implications, but also recommendations for tax policy.

The remainder of this article is organized as follows: After an overview of the literature on international tax planning and asymmetric taxation in section 2, the investment model's assumptions are presented in section 3. Section 4 points out the possible investment incentives resulting from loss offset restrictions using deterministic examples. In section 5 , the dominating effects are derived by means of Monte Carlo simulations. Section 6 summarizes and concludes.

\section{Literature}

The extensive literature on international tax planning ${ }^{2}$ often addresses subjects like the optimal legal structure of foreign activities ${ }^{3}$, optimal repatriation and financing strategies $^{4}$, and anti tax-avoidance provisions ${ }^{5}$. Investment effects of loss offset restrictions in an international context are rarely discussed ${ }^{6}$.

In the German-language literature on asymmetric taxation, the tax law perspective prevails $^{7}$ whereas the investment incentives are often disregarded. The international literature $^{8}$, in contrast, emphasizes the effects of asymmetric taxation on investment behavior. This is also true for the literature that critisizes the U.S. alternative minimum tax ${ }^{9}$ since it was implemented in $1987^{10}$.

Due to the non-linearity and the path-dependence of loss offset rules, numerical techniques

\footnotetext{
${ }^{2}$ Cf. Alworth (1988), e.g.

${ }^{3}$ Cf. Gordon/Jun (1993).

${ }^{4}$ Cf. Hartman (1985), Alworth (1988), Altshuler/Newlon (1993), Leechor/Mintz (1993), Sinn (1993), Grubert (1998), Wunder (1999), Babcock (2000), Altshuler/Grubert (2002), Kari/Ylä-Liedenpohja (2003).

${ }^{5}$ Cf. Weichenrieder (1996).

${ }^{6} \mathrm{Cf}$. Gérard/Weiner (2003) for loss-offset and formula apportionment and Lyon/Silverstein (1995) for the effects of the U.S. alternative minimum tax on multi-national corporations.

${ }^{7}$ Cf. Raupach/Böckstiegel (1999), Altfelder (2000), e.g.

${ }^{8}$ Cf. Domar/Musgrave (1944), Barlev/Levy (1975), Eeckhoudt/Hansen (1982), Auerbach (1986), Auerbach/Poterba (1987), MacKie-Mason (1990), Eeckhoudt/Gollier/Schlesinger (1997). For the empirical relevance cf. Mintz (1988) using effective tax rates and Altshuler/Auerbach (1990). The similarities between call options and taxes are discussed by Ball/Bowers (1982), Majd/Myers (1985), Majd/Myers (1987), Schnabel/Roumi (1990), Lund (1992), Lund (2000).

${ }^{9}$ The U.S. alternative minimum tax is not equivalent to the minimum tax discussed below, because it requires the calculation of a separate tax base and can be described as a parallel tax system.

${ }^{10}$ Cf. Bernheim (1989), Lyon (1990), Lyon (1997), Feenberg/Poterba (2003), Burman/Gale/Rohaly (2003), Burman/Gale/Rohaly (2002).
} 
are used to appraise investment projects with losses ${ }^{11}$. Some papers on asymmetric taxation ignore the tax impact on financial investment ${ }^{12}$ which may be a decisive factor for investment incentives.

While loss offset restrictions are natural links to quantitative international tax planning, both areas of tax literature are widely unrelated. Moreover, investment decisions under existing loss carryforwards have not been analyzed at all. For this reason, it is not yet clear whether the impact of asymmetric taxation on investment behavior is intensified or reduced in an international setting. It is the aim of this paper to correct this shortcoming by modeling both real and financial investment taking international taxation into account. We will analyze the impact of different domestic and foreign loss offset limitations on the relative advantage of real versus financial investment.

\section{Model design}

\subsection{Assumptions}

At time $t=0$, an investor with a finite time horizon of $T$ periods decides on the use of equity capital in the amount of $A_{0}$. It can be invested either in a real investment project with cash flows $C F_{t}(t=1, \ldots, T)$ or a financial investment with a constant pretax interest rate $i$. Borrowing is possible at the same interest rate $i$. Returning cash flows from real or financial investment are re-invested until the time horizon $T$. The real investment project as well as financial investment can be realized either in the investor's domestic business or in the foreign country. Pre-tax cash flows and the pre-tax interest rate are identical in the home country and in the foreign country.

In the following, we will consider a case that is related to German tax law. The investor operates either an individual enterprise or a partnership. This means that the domestic legal structure is fixed. In contrast, the legal structure of the foreign activities is still disposable. The legal structure determines whether double taxation occurs and which method can be applied to avoid it. To restrict complexity, only the foreign branch and the foreign subsidiary will be analyzed. It is assumed that a double taxation agreement exempts profits of a foreign branch ${ }^{13}$. This implies that branch profits are subject only to foreign taxation. There is no additional domestic tax on repatriations.

At first sight, the profits of a foreign subsidiary are subject only to foreign taxation, too. Under a classical corporation tax like in Germany and many other countries, shareholders are taxed upon repatriations. Therefore, dividends, capital gains and profits from liquidating a - domestic or foreign - corporation are subject to domestic personal income tax. As a consequence, the relative advantage or disadvantage of investment in a foreign subsidiary versus investment in a foreign branch or versus domestic investment is also determined by domestic taxation and with it by domestic loss offset rules.

\footnotetext{
${ }^{11}$ Cf. Haegert/Kramm (1977) who analyze the effects of a loss carryback on investment behavior. Cf. Majd/Myers (1985), Majd/Myers (1987).

${ }^{12}$ Cf. De Waegenaere/Sansing/Wielhouver (2001), partly Schnabel/Roumi (1990).

${ }^{13}$ Cf. Art. 7 (1) 1, 2. HS in combination with Art. 23 A (1) OECD double taxation convention.
} 
A pivotal determinant for the choice of location is the nominal tax rate. Since Germany is often regarded as a high-tax country ${ }^{14}$, we will assume that the domestic personal income tax rate is proportional, equals $\tau^{D}=40 \%$ and exceeds the foreign personal income tax rate of $\tau^{B}=30 \%$ and the foreign corporate tax rate of $\tau^{S}=20 \%{ }^{15}$.

We will assume terminal repatriation, which means that all cash flows (from real and financial investment) are re-invested in the initially chosen investment alternative. Only at the time horizon $T$, the investor receives a return of capital. Choice of the legal structure in $t=0$ is assumed irreversible. As a consequence, dividends of the foreign subsidiary are excluded for the entire time horizon. Of course, this assumption is quite restrictive, but it is necessary for reasons of transparency. Intertemporal optimization of repatriation policy is a very complex $\operatorname{task}^{16}$ that typically involves mixed-integer optimization problems. Integrating repatriation policy, it would become impossible to separate the investment incentives induced by loss offset rules, repatriation decisions, and choice of the legal structure. For domestic investment, withdrawals are excluded, too.

To isolate the effects of asymmetric taxation, we will assume that the tax base is calculated identically in both countries. Analogous to the standard model of capital budgeting with $\operatorname{taxes}^{17}$ the tax base is the difference between cash flows and depreciation deductions. For reasons of simplicity, we consider only linear depreciation allowances that are identical at home and abroad. Other non-cash accruals do not exist. In accordance with current law in Germany, interest income is fully taxable; there are no special tax rates. Positive and negative interest payments belong to the same income basket as profits from real investment. For lack of other income sources, there is only an internal offsetting of losses from real investment with possibly positive interest income.

If domestic investment is carried out the sum of earnings in the home country - as a first step towards computing the tax base - is calculated as:

$$
S o E_{t}^{D}=C F_{t}-\delta_{t}+\operatorname{Int} t_{t}^{I}
$$

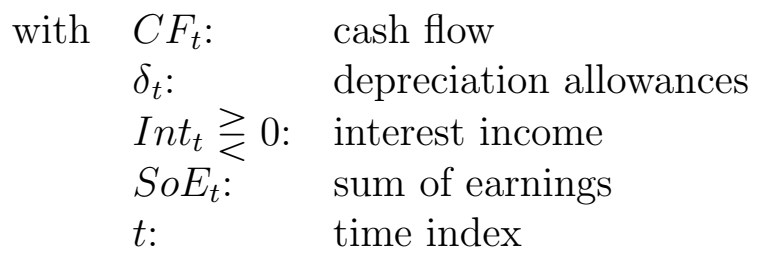

If investment is carried out in the foreign branch the sum of earnings in the foreign country can be computed analogously. In this case, the sum of earnings in the home country is

\footnotetext{
${ }^{14}$ Cf. EU commission (2001), pp. 91 ff., e.g.

${ }^{15}$ Superscripts ${ }^{D}$ indicate domestic variables, ${ }^{B}$ variables related to the foreign branch, ${ }^{S}$ variables in connection with the foreign subsidiary.

${ }^{16}$ Cf. Altshuler/Newlon (1993), Grubert (1998), Wunder (1999), Altshuler/Grubert (2002). In this paper, we do not optimize financial policy of the firm, because the interdependencies are too complex to separate them from the effects of loss offset rules.

${ }^{17}$ Cf. Wagner/Dirrigl (1980), Scholes et al. (2001).
} 
zero:

$$
\begin{aligned}
S o E_{t}^{* B} & =C F_{t}-\delta_{t}+\operatorname{Int} t_{t}^{B} \\
S o E_{t}^{B} & =0
\end{aligned}
$$

Asterisks indicate foreign tax parameters. Calculating the sum of earnings for the foreign subsidiary, the investor has to take into account that half of the capital gain ${ }^{18}$ from liquidating the corporation in the time horizon $T$ is taxable income on the individual level.

$$
\begin{aligned}
S o E_{t}^{* S} & =C F_{t}-\delta_{t}+I_{n} t_{t}^{S} \\
S o E_{t}^{S} & =0, \quad t=1, \ldots, T-1 \\
S_{O} E_{T}^{S} & =\frac{1}{2} \cdot\left(\text { Liqu }_{T}^{S}-A_{0}\right)
\end{aligned}
$$

with $\quad L i q u_{T}^{S}$ : terminal value of the foreign subsidiary

The latest available German income tax statistic from 1998 shows current loss carryforwards of about 300 billion EUR. Loss-offset limitations imposed by the tax legislation often intend to restrict the use of loss carryforwards. For this reason, it is sensible to integrate an exogenously-given initial loss carryforward at time $t=0$ that is derived from the investor's past activities. The initial loss carryforward may be zero or positive: $L_{0} \geq 0$. This assumption creates a novel decision situation that has been neglected by the literature.

To restrict the number of loss offset parameters, loss carrybacks are excluded ${ }^{19}$, and only loss carryforwards are permitted. Two limitations, a minimum tax and a time limit, restrict the use of loss carryforwards, both of which are currently practiced in several EU countries.

A minimum tax means that a fraction $\alpha$ of positive profits is subject to tax, regardless of existing loss carryforwards. Existing loss carryforwards can only be offset over a longer period of time. A minimum tax is levied in Austria ${ }^{20}$ since 2001 and in Germany ${ }^{21}$ since 2004. The tax base of period $t$ is defined as the maximum of the sum of earnings less loss carryforward at the beginning of the period and the fraction of profits that is at least taxable. If the sum of earnings is negative, the tax base is zero ${ }^{22}$.

$$
y_{t}=\max \left\{0 ; S_{o} E_{t}-L_{t-1} ; \alpha \cdot S_{o} E_{t}\right\}
$$

\footnotetext{
${ }^{18}$ This provision - the so-called half-income system - is a shareholder relief element in the classical corporation tax in Germany.

${ }^{19}$ Haegert/Kramm found as early as 1977 that the impact of loss carrybacks is negligible.

${ }^{20} \mathrm{Cf}$. $\S 2$ (2b) öEStG (Austrian income tax code).

${ }^{21} \mathrm{Cf} . \S 10 \mathrm{~d}(2) \mathrm{EStG}$ (German income tax code).

${ }^{22} \mathrm{~A}$ possible deduction from the minimum tax will be disregarded. According to $\S 10 \mathrm{~d}(2)$ EStG the deduction amounts to 1 million EUR. This means that the minimum tax can be neglected by taxpayers with a sum of earnings of less than 1 million EUR.
} 


$$
\begin{aligned}
& \text { with } L_{t} \text { : loss carryforward at end of period } t \\
& y_{t} \text { : taxable income } \\
& \alpha \text { : minimum tax fraction }
\end{aligned}
$$

A time limit on loss carryforwards can be found in several EU countries and in some tax reform proposals. It means that a loss that occurs in period $t$ can only be offset with profits of periods $t+1, \ldots, t+T_{f}$. The remaining sum is discarded. Consequently, the initial loss carryforward $L_{0}$ can be offset only in periods $t=1, \ldots, T_{f}$.

A loss carryforward at the time horizon $t=T$ cannot be offset any more. The investor terminates his economic activities at this point of time. Selling the loss carryforward to other taxpayers is excluded. Thus, the remaining loss carryforward is attached zero value.

\subsection{Measuring tax effects}

The criterion for the investment decision is the difference of the future values (FVs) of real and financial investment. Basically, it would also be possible to compute net present values instead, but this criterion would require FVs, too. The reason is that a limited loss offset always requires an explicit linkage of subsequent periods and with it a complete cash flow statement for both real and financial investment. An interest rate that mirrors the post-tax rate of return of financial investment correctly that is necessary for computing net present values can be derived only endogenously on the basis of $\mathrm{FVs}^{23}$. Therefore, FVs can be directly compared.

Cross-border investment alternatives imply a multitude of possible decision alternatives. Real as well as financial investment can be realized in the investor's domestic business, in the foreign branch, or in the foreign subsidiary. As a consequence, the optimal financial investment is not obvious. Rather, it emerges as a result of an optimization process and depends on loss offset parameters ${ }^{24}$ :

$$
F V_{F}^{\max }=\max \left\{F V_{F}^{D} ; F V_{F}^{B} ; F V_{F}^{S}\right\}
$$

with $F V_{F}^{B}: \quad$ future value of financial investment in the foreign branch $F V_{F}^{D}$ : future value of financial investment in the domestic business $F V_{F}^{S}$ : future value of financial investment in the foreign subsidiary $F V_{F}^{\max }$ : maximum future value of financial investment

This is also true for real investment:

$$
F V_{R}^{\max }=\max \left\{F V_{R}^{D} ; F V_{R}^{B} ; F V_{R}^{S}\right\}
$$

\footnotetext{
${ }^{23}$ The necessity for an endogenous interest rate is emphasized by Cooper/Franks (1983), Shevlin (1990).

${ }^{24}$ Financial investment is denoted with subscript ${ }_{F}$, real investment with subscript ${ }_{R}$.
} 
with $F V_{R}^{B}: \quad$ future value of real investment in the foreign branch $F V_{R}^{D}: \quad$ future value of real investment in the domestic business $F V_{R}^{S}$ : future value of real investment in the foreign subsidiary $F V_{R}^{\max }$ : maximum future value of real investment

The criterion for the investment decision is the difference of the optimal FVs:

$$
\Delta F V=F V_{R}^{\max }-F V_{F}^{\max }
$$

with $\Delta F V$ : difference of optimal future values of real and financial investment

The reference case for measuring the effects of particular loss offset parameters is the full and immediate loss offset ${ }^{25}$. Using this reference case, deviations from neutral loss offset can be identified. The measure for the impact of loss offset rules on investment behavior is the difference $\Delta$ between the differences of future values of real and financial investment under full loss offset $\triangle F V^{F L O}$ and under limited loss offset $\triangle F V^{L L O 26}$ :

$$
\Delta=\Delta F V^{F L O}-\Delta F V^{L L O}=\underbrace{\left(F V_{R}^{\max , F L O}-F V_{F}^{\max , F L O}\right)}_{\begin{array}{c}
\text { difference of future values } \\
\text { under full loss offset }
\end{array}}-\underbrace{\left(F V_{R}^{\max , L L O}-F V_{F}^{\max , L L O}\right)}_{\begin{array}{c}
\text { difference of future values } \\
\text { under limited loss offset }
\end{array}}
$$

with $F V_{F}^{\max , F L O}: \quad$ maximum future value of financial investment under FLO

$F V_{F}^{\max , L L O}:$ maximum future value of financial investment under LLO

$F V_{R}^{\max , F L O}:$ maximum future value of real investment under FLO

$F V_{R}^{\max , L L O}:$ maximum future value of real investment under LLO

$\Delta: \quad$ difference of differences of future values

$\triangle F V^{F L O}: \quad$ difference of future values under FLO

$\triangle F V^{L L O}$ : difference of future values under LLO

$\Delta$ reveals the deviation of the decision criterion from neutral loss offset. A positive (negative) value indicates that real investment is taxed discriminatory (preferentially) compared to neutral taxation. A loss offset paradox is characterized by negative values for $\Delta$. The sign and value of $\Delta$ are determined by loss offset parameters as well as the cash flow structure and rate of return of the underlying real investment.

\section{Deterministic cash flows}

In the following section, the possible investment incentives of loss offset limitations are described by means of deterministic examples with different cash flow structures.

\footnotetext{
${ }^{25}$ Cf. Schneider (1992), e.g.

${ }^{26}$ Values on the basis of full, immediate loss offset are denoted with superscript ${ }^{F L O}$, values on the basis on incomplete or limited loss offset with superscript ${ }^{L L O}$.
} 


\subsection{Declining cash flows}

We look at an investment project with cash flows mainly at the beginning of the economic life that decline over time. This effect can be observed when a mature product is imitated by competitors. In the following example, the real investment project 1 with an initial outlay of $A_{0}=1$ million EUR and the following cash flow will be examined:

Table 1: cash flow of project 1 (in ,000 EUR)

\begin{tabular}{c|cccccccccc}
$t$ & 1 & 2 & 3 & 4 & 5 & 6 & 7 & 8 & 9 & 10 \\
\hline$C F_{t}$ & 400 & 300 & 200 & 125 & 100 & 50 & 50 & 50 & 50 & 50
\end{tabular}

This project yields a positive pre-tax NPV of 26,991 EUR (difference of pre-tax FVs: $+70,008$ EUR). Since the present value of linear depreciation allowances falls short of the present value of economic depreciation, the difference of post-tax FVs under full loss offset is negative as can be seen from the following table:

Tabelle 2: future values of project 1 (in EUR)

\begin{tabular}{c|c|c} 
future value & pre-tax case & $F L O, L L O$ with $L_{0}=0, \alpha=0, T_{f}=T$ \\
\hline$F V_{F}^{D}$ & $2,593,742$ & $1,790,848$ \\
$F V_{F}^{B}$ & $2,593,742$ & $\mathbf{1 , 9 6 7 , 1 5 1}$ \\
$F V_{F}^{S}$ & $2,593,742$ & $1,927,140$ \\
\hline$F V_{R}^{D}$ & $2,663,750$ & $1,755,830$ \\
$F V_{R}^{B}$ & $2,663,750$ & $\mathbf{1 , 9 4 5 , 6 5 9}$ \\
$F V_{R}^{S}$ & $2,663,750$ & $1,926,996$ \\
\hline$\Delta F V^{D}$ & 70,008 & $-35,017$ \\
$\Delta F V$ & 70,008 & $\mathbf{- 2 1 , 4 9 2}$
\end{tabular}

The optimal ways of realizing real and financial investment are printed in bold face. In addition to the difference of optimal FVs $\triangle F V$ the difference of domestic FVs $\triangle F V^{D}$ is given, too. In our example, the foreign branch would be the optimal way to realize real as well as financial investment. Without an initial loss carryforward $L_{0}$, the choice of location could be based on nominal tax rates in this case, which would be rather trivial. In contrast, for initial loss carryforwards of $L_{0}=100,000$ or $L_{0}=650,000$, the FVs are given by: 
Table 3: FVs of project 1 with initial loss carryforward (in EUR)

\begin{tabular}{c|c|c|c|c} 
& \multicolumn{2}{|c|}{$L_{0}=100,000$} & \multicolumn{2}{c}{$L_{0}=650,000$} \\
future value & $F L O$ & $\alpha=0, T_{f}=T$ & $F L O$ & $\alpha=0, T_{f}=T$ \\
\hline$F V_{F}^{D}$ & $1,862,482$ & $1,858,427$ & $2,256,468$ & $\mathbf{2 , 1 7 5 , 1 6 8}$ \\
$F V_{F}^{B}$ & $\mathbf{2 , 0 4 5 , 8 3 7}$ & $\mathbf{1 , 9 6 7 , 1 5 1}$ & $\mathbf{2 , 4 7 8 , 6 1 1}$ & $1,967,151$ \\
$F V_{F}^{S}$ & $2,004,226$ & $1,967,140$ & $2,428,196$ & $2,158,925$ \\
\hline$F V_{R}^{D}$ & $1,827,464$ & $1,823,409$ & $2,221,451$ & $\mathbf{2 , 1 7 7 , 7 3 7}$ \\
$F V_{R}^{B}$ & $\mathbf{2 , 0 2 4 , 3 4 5}$ & $1,945,659$ & $\mathbf{2 , 4 5 7 , 1 1 8}$ & $1,945,659$ \\
$F V_{R}^{S}$ & $2,004,082$ & $\mathbf{1 , 9 6 6 , 9 9 6}$ & $2,428,053$ & $2,158,746$ \\
\hline$\Delta F V^{D}$ & $-35,017$ & $-35,017$ & $-35,017$ & $+2,569$ \\
$\Delta F V$ & $-\mathbf{2 1 , 4 9 2}$ & $-\mathbf{1 5 5}$ & $-\mathbf{2 1 , 4 9 2}$ & $+\mathbf{2 , 5 6 9}$ \\
$\Delta$ & & $-21,338$ & & $-24,062$
\end{tabular}

A domestic initial loss carryforward $L_{0}>0$ implies that domestic alternatives remain (partially) tax-free. Consequently, domestic investment alternatives gain an advantage over foreign investment alternatives. Moreover, the foreign subsidiary is taxed preferentially compared to the foreign branch, because half of the capital gain from liquidating the foreign corporation would be subject to domestic taxation without initial loss carryforward $\left(L_{0}=0\right)$ and remains (partially) tax-free with initial loss carryforward $\left(L_{0}>0\right)$. The foreign branch is unaffected by domestic tax parameters. For sufficiently small values of $L_{0}$, the foreign branch is the optimal alternative, for medium-sized values, it is the foreign subsidiary. If $L_{0}$ is sufficiently high, domestic investment will be optimal. For $L_{0}>617,835 \mathrm{EUR}$, domestic financial investment is the optimal financial investment, for $L_{0}>618,424 \mathrm{EUR}$, domestic real investment is the optimal way of realizing real investment. Since these thresholds are not identical, the optimal legal structure of real and financial investment may differ. This is one reason for the non-monotonicity of the difference of FVs with respect to $L_{0}$.

From the negative values for $\Delta$ it can be seen that the unlimited loss carryforward favors real over financial investment in this setting if an initial loss carryforward exists. Since restricting the loss offset rules favors real investment this situation can be described as a loss offset paradox.

The trade-off between a high domestic nominal tax rate and the possibility to offset loss carryforwards in contrast to low foreign nominal tax rates and limited possibilities to offset loss carryforwards implies a domestic lock-in effect. Whether domestic loss offset rules favor real or financial investment remains to be analyzed and depends on the structure of cash flows and the rate of return.

Introducing a minimum tax may intensify the trade-off and with it the lock-in effect. The critical thresholds of $L_{0}$ above which domestic investment is optimal decline after the introduction of a minimum tax: 
Table 4: indifference values of $L_{0}$ for project 1

\begin{tabular}{l|c|c|c|c} 
indifference value $L_{0}^{\sim}$ & $\alpha=0 ; T_{f}=T$ & $\alpha=0.25 ; T_{f}=T$ & $\alpha=0.4 ; T_{f}=T$ & $\alpha=0 ; T_{f}=5$ \\
\hline financial investment & 617,835 & 531,930 & 488,832 & 274,170 \\
real investment & 618,425 & 535,466 & 493,720 & 280,898
\end{tabular}

The more restrictive the minimum tax, the more pronounced the domestic lock-in effect. The attractiveness of domestic investment increases. In other words: under a minimum tax, more investors choose domestic investment alternatives than without minimum $\operatorname{tax}^{27}$. In contrast, a minimum tax does not necessarily favor real investment. Rather, the impact of varying the minimum tax fraction $\alpha$ is ambiguous, as can be seen from the fluctuating values of $\Delta$ in the following table:

Table 5: future values of project 1 with initial loss carryforward

\begin{tabular}{c|c|c|c|c|c} 
& \multicolumn{5}{|c}{$L_{0}=550,000$} \\
future value & $F L O$ & $\alpha=0$ & $\alpha=0.25$ & $\alpha=0.4$ & $\alpha=0$ \\
\hline$T_{f}$ & - & $T$ & $T$ & $T$ & 5 \\
\hline$F V_{F}^{D}$ & $2,184,834$ & $2,122,835$ & $\mathbf{2 , 1 1 0 , 1 0 4}$ & $\mathbf{2 , 0 9 8 , 3 1 4}$ & $\mathbf{2 , 1 2 2 , 8 3 5}$ \\
$F V_{F}^{B}$ & $\mathbf{2 , 3 9 9 , 9 2 5}$ & $1,967,151$ & $1,967,151$ & $1,967,151$ & $1,967,151$ \\
$F V_{F}^{S}$ & $2,351,111$ & $\mathbf{2 , 1 4 7 , 1 4 0}$ & $2,100,979$ & $2,066,211$ & $1,927,140$ \\
\hline$F V_{R}^{D}$ & $2,149,817$ & $2,117,592$ & $\mathbf{2 , 1 0 9 , 0 5 5}$ & $\mathbf{2 , 0 9 8 , 7 0 1}$ & $\mathbf{2 , 1 1 7 , 5 9 2}$ \\
$F V_{R}^{B}$ & $\mathbf{2 , 3 7 8 , 4 3 2}$ & $1,945,659$ & $1,945,659$ & $1,945,659$ & $1,945,659$ \\
$F V_{R}^{S}$ & $2,350,967$ & $\mathbf{2 , 1 4 6 , 9 9 6}$ & $2,100,808$ & $2,066,046$ & $1,926,996$ \\
\hline$\Delta F V^{D}$ & $-35,017$ & $-5,244$ & $-1,049$ & +387 & $-5,244$ \\
$\Delta F V$ & $-\mathbf{2 1 , 4 9 2}$ & $-\mathbf{1 4 4}$ & $-\mathbf{1 , 0 4 9}$ & $+\mathbf{3 8 7}$ & $-\mathbf{5 , 2 4 4}$ \\
$\Delta$ & & $-21,349$ & $-20,443$ & $-21,880$ & $-16,249$
\end{tabular}

Restricting the time limit of a loss carryforward may induce similar investment incentives as a minimum tax. This is denoted in the right column of table 5. Under a time limit of, say, $T_{f}=5$ the FV of investment in the foreign branch remains unchanged. Under the repatriation assumptions, the FV of investment in the foreign subsidiary declines significantly, because the capital gain from liquidating the foreign subsidiary cannot be offset against the initial loss carryforward that was discarded in the meantime. In the above example, this effect does not affect domestic investment alternatives. However, discriminating against the foreign subsidiary induces a relative improvement for domestic investment $^{28}$.

Beneficial tax treatment of domestic investment does not necessarily favor real investment as can be seen from the example $L_{0}=350,000$. In this setting, the difference of FVs is

\footnotetext{
${ }^{27}$ As is discussed below, the introduction of a minimum tax may have the opposite effect - a push-outeffect - if the investor has no initial loss carryforward $\left(V V_{0}=0\right)$.

${ }^{28}$ This effect is also related to the repatriation policy assumed here.
} 
negative and $\Delta$ is positive which means that real investment is taxed discriminatory compared to financial investment:

$$
\begin{aligned}
F V_{R}^{\max }-\left.F V_{F}^{\max }\right|_{L_{0}=350,000} & =F V_{R}^{D}-F V_{F}^{D}=1,990,445-2,012,113=-21,668 \\
\Delta & =175
\end{aligned}
$$

Comparing this result with table 5 , it is obvious that the sign of $\Delta$ depends on the initial loss carryforward. Whereas an initial loss carryforward of $L_{0}=550,000$ induces a favorable treatment of real investment $(\Delta=-16,249)$, real investment is discriminated against for $L_{0}=350,000$.

The critical thresholds of $L_{0}$ above which domestic investment is optimal decline after a time limit on loss carryforwards is introduced. This means that the domestic lock-in effect is strengthened. Like under the minimum tax, domestic investment becomes advantageous for a growing number of investors. However, without initial loss carryforward $\left(L_{0}=0\right)$ the attractiveness of domestic investment recedes if new losses are possible.

Varying the foreign minimum tax fraction $\alpha^{*}$ and the foreign time limit on loss carryforwards $T_{f}^{*}$ does not induce any noticeable investment effects in the parameter setting considered here.

\subsection{Rising cash flows}

Introducing innovative products often generates starting losses. If the product is successful, cash flows rise over time. In contrast to the imitative project discussed above, innovations are likely to be discriminated against by loss offset limitations. This effect becomes obvious from project 2 with rising cash flows. The initial outlay is again $A_{0}=1$ million EUR.

Table 6: cash flow of project 2 (in ,000 EUR)

\begin{tabular}{c|cccccccccc}
$t$ & 1 & 2 & 3 & 4 & 5 & 6 & 7 & 8 & 9 & 10 \\
\hline$C F_{t}$ & -200 & -100 & -50 & 100 & 200 & 300 & 400 & 500 & 600 & 600
\end{tabular}

In contrast to the imitative project, this innovative project causes starting losses. In the pre-tax case, this project is slightly disadvantageous; the pre-tax NPV is $-15,899 \mathrm{EUR}$ (difference of pre-tax FVs: -41,239 EUR). Now, the present value of linear depreciation allowances exceeds the present value of economic depreciation. As a result, the difference of post-tax NPVs under full loss offset is positive; a classical tax paradox occurs. Table 7 denotes the pre-tax FVs in the different cases: 
Table 7: FVs of project 2

\begin{tabular}{c|c|c} 
future value & pre-tax case & $F L O, L_{0}=0$ \\
\hline$F V_{F}^{D}$ & $2,593,742$ & $1,790,848$ \\
$F V_{F}^{B}$ & $2,593,742$ & $\mathbf{1 , 9 6 7 , 1 5 1}$ \\
$F V_{F}^{S}$ & $2,593,742$ & $1,927,140$ \\
\hline$F V_{R}^{D}$ & $2,552,504$ & $2,021,222$ \\
$F V_{R}^{B}$ & $2,552,504$ & $\mathbf{2 , 1 7 0 , 4 3 6}$ \\
$F V_{R}^{S}$ & $2,552,504$ & $2,047,913$ \\
\hline$\Delta F V^{D}$ & $-41,239$ & 230,375 \\
$\Delta F V$ & $-41,239$ & $\mathbf{2 0 3 , 2 8 5}$
\end{tabular}

Assuming varying initial loss carryforwards $L_{0}>0$ und no minimum tax results in the following FVs and FV differences:

Table 8: FVs of project 2 with varying values of $L_{0}$

\begin{tabular}{c|c|c|c|c} 
& \multicolumn{2}{|c}{$L_{0}=100,000$} & \multicolumn{2}{c}{$L_{0}=650,000$} \\
future value & $F L O$ & $\alpha=0$ & $F L O$ & $\alpha=0$ \\
\hline$F V_{F}^{D}$ & $1,862,482$ & $1,858,427$ & $2,256,468$ & $\mathbf{2 , 1 7 5 , 1 6 8}$ \\
$F V_{F}^{B}$ & $\mathbf{2 , 0 4 5 , 8 3 7}$ & $\mathbf{1 , 9 6 7 , 1 5 1}$ & $\mathbf{2 , 4 7 8 , 6 1 1}$ & $1,967,151$ \\
$F V_{F}^{S}$ & $2,004,226$ & $1,967,140$ & $2,428,196$ & $2,158,925$ \\
\hline$F V_{R}^{D}$ & $2,092,856$ & $1,948,624$ & $2,486,843$ & $2,186,102$ \\
$F V_{R}^{B}$ & $\mathbf{2 , 2 4 9 , 1 2 2}$ & $\mathbf{2 , 0 6 2 , 3 5 1}$ & $\mathbf{2 , 6 8 1 , 8 9 6}$ & $2,062,351$ \\
$F V_{R}^{S}$ & $2,124,998$ & $2,018,695$ & $2,548,969$ & $\mathbf{2 , 2 2 3 , 3 6 9}$ \\
\hline$\Delta F V^{D}$ & $+230,375$ & $+90,197$ & $+230,375$ & $+10,935$ \\
$\Delta F V$ & $+\mathbf{2 0 3 , 2 8 5}$ & $+\mathbf{9 5 , 2 0 0}$ & $+\mathbf{2 0 3 , 2 8 5}$ & $+\mathbf{4 8 , 2 0 1}$ \\
$\Delta$ & & $+108,085$ & & $+155,084$
\end{tabular}

As indicated by increasing values of $\Delta$, the real investment project is discriminated against by increasing values of $L_{0}$ in this parameter setting, even without a minimum tax. The investment incentives of a minimum tax for an initial loss carryfoward of $L_{0}=550,000$ are given in table 9 : 
Table 9: FVs of project 2 under a minimum tax

\begin{tabular}{c|c|c|c|c|c} 
& \multicolumn{5}{|c}{$L_{0}=550,000$} \\
\hline future value & $F L O$ & $\alpha=0$ & $\alpha=0.25$ & $\alpha=0.4$ & $\alpha=0 ; T_{f}=5$ \\
\hline$F V_{F}^{D}$ & $2,184,834$ & $2,122,835$ & $\mathbf{2 , 1 1 0 , 1 0 4}$ & $\mathbf{2 , 0 9 8 , 3 1 4}$ & $\mathbf{2 , 1 2 2 , 8 3 5}$ \\
$F V_{F}^{B}$ & $\mathbf{2 , 3 9 9 , 9 2 5}$ & $1,967,151$ & $1,967,151$ & $1,967,151$ & $1,967,151$ \\
$F V_{F}^{S}$ & $2,351,111$ & $\mathbf{2 , 1 4 7 , 1 4 0}$ & $2,100,979$ & $2,066,211$ & $1,927,140$ \\
\hline$F V_{R}^{D}$ & $2,415,209$ & $2,143,702$ & $2,128,723$ & $2,115,254$ & $1,880,371$ \\
$F V_{R}^{B}$ & $\mathbf{2 , 6 0 3 , 2 1 0}$ & $2,062,351$ & $2,062,351$ & $2,062,351$ & $\mathbf{2 , 0 6 2 , 3 5 1}$ \\
$F V_{R}^{S}$ & $2,471,883$ & $\mathbf{2 , 1 9 8 , 6 9 5}$ & $\mathbf{2 , 1 6 2 , 2 0 0}$ & $\mathbf{2 , 1 2 5 , 4 9 9}$ & $1,978,695$ \\
\hline$\Delta F V^{D}$ & $+230,375$ & $+20,867$ & $+18,619$ & $+16,940$ & $-242,465$ \\
$\Delta F V$ & $+\mathbf{2 0 3 , 2 8 5}$ & $+\mathbf{5 1 , 5 5 5}$ & $+\mathbf{5 2 , 0 9 6}$ & $+\mathbf{2 7 , 1 8 5}$ & $-\mathbf{6 0 , 4 8 4}$ \\
$\Delta$ & & $+151,730$ & $+151,189$ & $+176,100$ & $+263,769$
\end{tabular}

The non-monotonicity of $\Delta$ with respect to $\alpha$ implies ambiguous investment incentives of a minimum tax. A minimum tax fraction of $\alpha=0.25$ induces a smaller discrimination of real investment, whereas $\alpha=0.4$ causes a greater discrimination compared to unlimited loss carryforward. If the analysis is restricted to domestic investment alternatives, the ambiguity also holds.

The lock-in effect from the previous example can be confirmed for project 2 , too. The critical thresholds, above which domestic investment alternatives are optimal, tend to decline due to the introduction of a minimum tax. For rising cash flows, this effect is less pronounced than for imitative projects. The following table displays the critical thresholds $L_{0}^{\sim}$ :

Table 10: critical thresholds of $L_{0}$ for project 2

\begin{tabular}{l|c|c|c|c} 
critical threshold $L_{0}^{\sim}$ & $\alpha=0$ & $\alpha=0.25$ & $\alpha=0.4$ & $T_{f}=5$ \\
\hline financial investment & 617,835 & 531,930 & 488,832 & 274,170 \\
real investment & 737,893 & 657,084 & 575,614 & -
\end{tabular}

In this example, the critical threshold for real investment exceeds the one for financial investment. At first sight, introduction of a minimum tax seems reasonable from a fiscal perspective. Loss offset restrictions can induce a domestic lock-in effect and with it additional tax revenues. However, such a fiscal strategy may fail. The example $T_{f}=5$ for project 2 indicates that under particular parameters, domestic real investment may never be optimal for an individual investor. In this case, there is no value of the initial loss carryforward that implies realization of domestic real investment. The discrimination of real investment is clarified by the right column of table 9. Limiting the loss carryforward time even leads to a negative difference of FVs and to a very high $\Delta$-value.

For a minimum tax fraction $\alpha=0.5$ there is no critical threshold of $L_{0}$ either. This means that the investor will never carry out domestic real investment in this case. These 
examples indicate that restrictive loss offset limitations may impose severe disadvantages, especially for innovative investment projects.

As in the previous example, varying foreign loss offset parameters induces no important investment incentives. The critical threshold of $L_{0}$ for $\alpha=0, T_{f}=T, T_{f}^{*}=5$ amounts to $\tilde{L_{0}}=709,359 \mathrm{EUR}$ compared to $\tilde{L_{0}}=737,893 \mathrm{EUR}$ for $T_{f}=T$. For $T_{f}=T_{f}^{*}=5$ there still exists no critical threshold; domestic real investment is never optimal. A similar effect can be observed for a foreign minimum tax $\left(\alpha^{*}=0.5\right)$. Without domestic minimum tax, the critical threshold decreases to $L_{0}^{\sim}=720,500$ EUR. Consequently, it is ambiguous whether a lock-in effect or a push-out effect occurs.

In addition to a domestic initial loss carryforward at time $t=0$, a foreign initial loss carryforward $L_{0}^{*}$ is conceivable. Is this case, the conclusions would be reversed: A foreign loss carryforward induces a foreign lock-in effect (a push-out effect from domestic perspective) that would be intensified by domestic loss offset restrictions. However, this case is rather trivial because foreign investment already benefits from lower nominal tax rates and would be further favored by initial foreign loss carryforwards.

Due to the large number of variables the possible investment effects of loss offset limitations are very complex. Nevertheless, it can be shown that seemingly paradox investment incentives can be observed in domestic as well as cross-border settings. Whenever an initial loss carryforward exists, unambiguous results are excluded.

\section{Monte Carlo simulations}

Due to non-linear functions and state-dependent tax payments, modeling real-world loss offset rules is quite demanding. Although analytical models would be desirable, even twoor three-period cases are too complex for economic conclusions. In contrast, numerical cash flow statements are easily applicable, even in multi-period cases with complex loss offset rules. To extract representative information from cash flow statements Monte Carlo simulations with uncertain cash flows are conducted.

\subsection{Model design}

The structure of cash flows has a significant impact on the investment incentives of loss offset restrictions. Thus, we need the possibility to vary the drift of the cash flow process using distribution parameters. Starting with a deterministic value $C F_{0}$, the cash flow increments $\varepsilon_{t}$ from period $t-1$ to period $t$ are assumed to be independent and identically normally distributed with mean $\mu$ und variance $\sigma^{2}{ }^{29}$

$$
C F_{t}-C F_{t-1}=\varepsilon_{t} \underset{\text { iid }}{\sim} N\left(\mu, \sigma^{2}\right), \quad t=1, \ldots, T
$$

\footnotetext{
${ }^{29}$ Cf. Niemann (2003), pp. 23 ff.
} 
with $\varepsilon_{t}$ : increment of the cash flow from $t-1$ to $t$

$\mu$ : $\quad$ mean of the increment

$\sigma^{2}$ : variance of the increment.

Choosing the parameter $\mu<0(>0)$, it is possible to model cash flows that are expected to decline (increase) over time. Adjusting the starting value $C F_{0}$ generates cash flows with varying expected rates of return. Since each cash flow possesses its own $\Delta$-value, we will use the arithmetic mean $\bar{\Delta}$ to evaluate the investment effects. For the following simulations, the parameters from table 11 are applied.

Table 11: parameters used for the Monte Carlo simulations

\begin{tabular}{l|l} 
pre-tax interest rate: & $i=0.1$ \\
\hline initial domestic loss carryforward: & $L_{0} \in\{0 ; \ldots ; 750,000\}$ \\
\hline value of loss carryforwards at time $t=T:$ & $l_{T}=0$ \\
\hline number of simulations for each parameter setting: & $n=25,000$ \\
\hline domestic income tax rate: & $\tau^{I}=0.4$ \\
\hline foreign income tax rate (branch): & $\tau^{B}=0.3$ \\
\hline foreign corporate tax rate (subsidiary): & $\tau^{K}=0.2$ \\
\hline time horizon: & $T=10$ \\
\hline domestic time of loss carryforward: & $T_{f} \in\{5 ; T\}$ \\
\hline foreign time of loss carryforward: & $T_{f}^{*} \in\{5 ; T\}$ \\
\hline domestic minimum tax fraction: & $\alpha \in\{0 ; 0.4\}$ \\
\hline foreign minimum tax fraction: & $\alpha^{*} \in\{0 ; 0.5\}$ \\
\hline standard deviation of $\varepsilon_{t}:$ & $\sigma^{2}=50,000$ \\
\hline depreciation allowances: & linear
\end{tabular}

Due to the large number of parameters we can expect only conditional statements with regard to the investment effects of loss offset rules. However, the most important parameters seem to be the expected structure of cash flows and the expected rate of return. Consequently, we will look at marginal and infra-marginal investment with declining and increasing cash flows.

For the taxational assumptions, we refer to section 3.1. In particular, it is assumed that there is an exogenous initial loss carryforward $L_{0} \geq 0$ at time $t=0$. Again, loss carryforwards that phase out at time $t=T$ are attached zero value.

The following figures are intended to clarify the fundamental problem of incomplete loss offset in a stochastic environment. As is obvious from figure 1 (left), asymmetric taxation of profits and losses induces an asymmetric distribution of FVs of real investment. This is also true if optimal real investment is considered. Figure 2 (right) displays the frequency distribution of $\Delta$, which is the relative disadvantage of real versus financial investment that is attributable to limited loss offset. From the origin it can be seen that many projects are 
favored a little, whereas a couple of projects are severely penalized. Varying loss offset parameters induces variations in the frequency distribution and with it in investment behavior.

Figure 1

frequency distribution of the maximum

FV of real investment $F V_{R}^{\max }$
Figure 2

frequency distribution of $\Delta$

$$
C F_{0}=399,018 ; \mu=-50,000 ; L_{0}=500,000 ; \alpha=0 ; T_{f}=T
$$
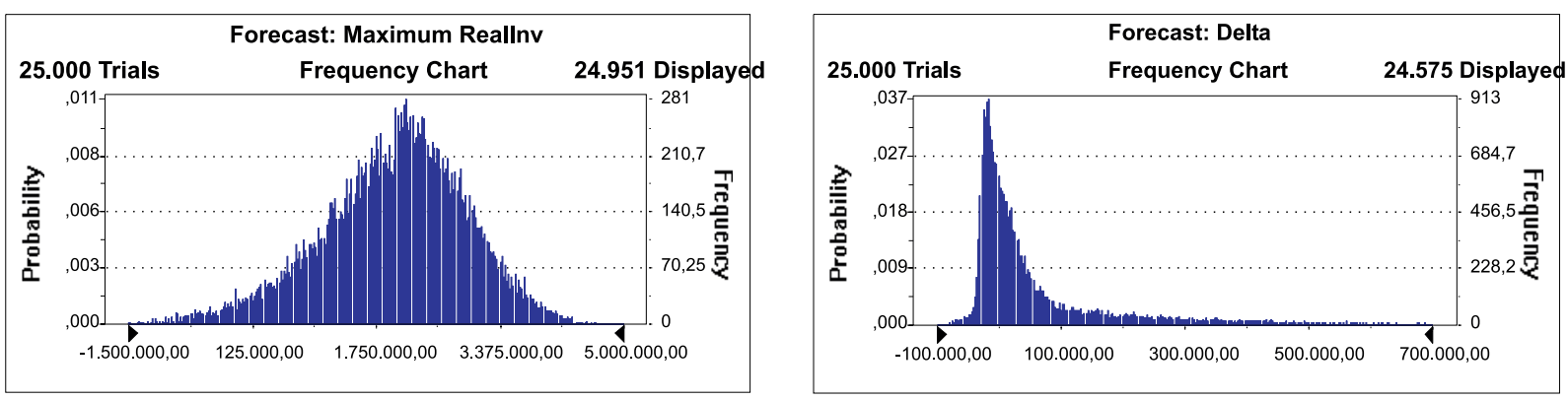

\subsection{Declining cash flows}

Cash flows that are expected to decline over time are associated with investment projects on mature markets that are not very risky. This pattern can be replicated with negative values for $\mu$. In the following, we present the results for $\mu=-50,000$ for initial cash flows of $C F_{0}=399,018$ and $C F_{0}=624,776$. These starting values $C F_{0}$ correspond to expected marginal (infra-marginal) investment with expected pre-tax rates of return of $10 \%$ and $20 \%$, respectively. The associated results are shown in tables 12-15.

For the parameters $C F_{0}=399,018$ and $\mu=-50,000$, the project is an expected marginal investment. The contents of tables 12-19 are as follows: Line 1 denotes the starting cash flow $C F_{0}$ that corresponds to the expected rate of return. Line 2 consists of the loss offset parameters. The percentage of advantageous projects with a positive difference of pre-tax FVs is denoted in line 3. Values around 50\% indicate expected marginal projects, values around $99 \%$ expected infra-marginal projects. If the present value of linear depreciation allowances exceeds (falls short of) the present value of economic depreciation, the percentage of advantageous projects increases (declines) compared to the pre-tax case. Line 4 shows the percentage of advantageous projects after taxes under full loss offset in the domestic case, line 5 in the international case. For the different types of limited loss offset, the associated percentages of positive differences of FVs can be seen in lines 6 and 7. Lines 8 and 9 represent the fraction of domestic investment alternatives and domestic real investment, respectively. Here, it it shown whether domestic or foreign investment is favored by loss offset rules.

After these percentage values, the mean differences of FVs in the pre-tax case, in the posttax case under full loss offset and in the post-tax case for limited loss offset are printed in lines 10-14. Lines 11 and 13 contain the domestic values in addition to the international 
values in order to analyze the impact of cross-border investment alternatives. The arithmetic mean of $\Delta$, which denotes the average relative discrimination of real investment is given in line 15 for the domestic case and in line 17 for international investment. Since $\Delta$ is distributed highly asymmetrically, the percentage of negative values, i.e., the fraction of loss offset paradox is given, too.

Table 12: investment effects of initial loss carryforwards

\begin{tabular}{|c|c|c|c|c|c|}
\hline 1 & $C F_{0}$ & \multicolumn{4}{|c|}{$\begin{array}{c}\alpha=0 ; T_{f}=T_{f}^{*}=T \\
399,018\end{array}$} \\
\hline 2 & $L_{0}$ & 0 & 250,000 & 500,000 & 750,000 \\
\hline 3 & $\%$ with $\Delta F V>0$ & \multicolumn{4}{|c|}{$50,02 \%$} \\
\hline 4 & $\%$ with $\Delta F V_{\text {domestic }}^{F L O}>0$ & \multicolumn{4}{|c|}{$44,72 \%$} \\
\hline 5 & $\%$ with $\Delta F V^{F L O}>0$ & $46.08 \%$ & $46.068 \%$ & $46.064 \%$ & $46.064 \%$ \\
\hline 6 & $\%$ with $\Delta F V_{\text {domestic }}^{L L O}>0$ & $43.78 \%$ & $44.336 \%$ & $45.332 \%$ & $46.568 \%$ \\
\hline 7 & $\%$ with $\Delta F V^{L L O}>0$ & $45.716 \%$ & $47.204 \%$ & $47.204 \%$ & $46.636 \%$ \\
\hline 8 & \% domestic investment & \multicolumn{3}{|c|}{$0 \%$} & $60 \%$ \\
\hline 9 & $\%$ domestic $\mathrm{r}$ & \multicolumn{3}{|c|}{$0 \%$} & $6.636 \%$ \\
\hline 10 & $\varnothing \Delta F V$ & \multirow{2}{*}{\multicolumn{4}{|c|}{$\begin{array}{c}-1,393 \\
-94,561\end{array}$}} \\
\hline 11 & $\varnothing \Delta F V_{\text {domestic }}^{F L O}$ & & & & \\
\hline 12 & $\varnothing \Delta F V^{F L O}$ & $-69,265$ & $-71,564$ & $-73,578$ & $-75,338$ \\
\hline 13 & $\varnothing \Delta F V_{\text {domes }}^{L L O}$ & $-233,474$ & $-212,921$ & $-193,502$ & $-187,151$ \\
\hline 14 & $\varnothing \Delta F V^{L L O}$ & $-146,925$ & $-147,643$ & $-150,338$ & $-147,616$ \\
\hline 15 & $\varnothing \Delta_{\text {domestic }}$ & 138,913 & 118,360 & 98,941 & 92,590 \\
\hline 16 & $\%$ with $\Delta_{\text {domestic }}<0$ & $0 \%$ & $47.52 \%$ & $54.864 \%$ & $61.116 \%$ \\
\hline 17 & $\varnothing \Delta$ & 77,660 & 76,079 & 76,759 & 72,278 \\
\hline 18 & $\%$ with $\Delta<0$ & $0 \%$ & $43.536 \%$ & $38.976 \%$ & $40.584 \%$ \\
\hline
\end{tabular}

The investment effects of varying the initial loss carryforward $L_{0}$ are summarized in table 12. Since the present value of linear depreciation allowances falls short of the average present value of economic depreciation, the arithmetic mean of the difference of FVs is negative (lines 11-14), and the percentage of advantageous real investment decreases compared to the pre-tax case (lines 3-7).

As already stated in the deterministic examples, an initial loss carryforward exhibits severe implications on the relative advantage of different investment alternatives. In this case, no special loss offset limitations exist, that means there is no minimum tax or time limit on loss carryforwards. Thus, loss carryforwards are unlimited. As could be expected, an initial loss carryforward favors domestic investment. Whereas no single domestic investment project is chosen for initial loss carryforwards of up to $L_{0} \leq 500,000$, domestic investment predominates for $L_{0}=750,000$. However, of the $60 \%$ domestic investment alternatives, only $6.636 \%$ are domestic real investment (lines 8 and 9).

Assuming cash flows that are expected to decrease over time, real investment is favored by increasing initial loss carryforwards. This effect can be recognized from the increased 
fraction of advantageous projects (lines 4 and $6 / 5$ and 7 ) and from the lower arithmetic means of $\Delta$ (lines 15 and 17). In the domestic case, the percentage of loss offset paradox increases with $L_{0}$ whereas the effect is ambiguous in the international case. The reason is that the loss offset effect interferes with a different choice of investment alternatives.

$\Delta$ exaggerates the discrimination of real investment due to the zero valuation of remaining loss carryforwards at time $t=T$. Valuing vanishing loss carryforwards with a positive constant would reduce the arithmetic mean of $\Delta$ and increase the percentage of loss offset paradox. However, such a valuation seems arbitrary.

The effects of a domestic minimum tax on real investment with expected decreasing cash flows can be seen from table 13:

Table 13: investment incentives of a domestic minimum tax

\begin{tabular}{|c|c|c|c|}
\hline \multirow{3}{*}{$\frac{1}{2}$} & \multicolumn{3}{|c|}{$L_{0}=500,000 ; T_{f}=T_{f}^{*}=T$} \\
\hline & $C F_{0}$ & \multicolumn{2}{|c|}{399,018} \\
\hline & $\alpha$ & 0 & 0,4 \\
\hline 3 & $\%$ with $\Delta F V>0$ & \multicolumn{2}{|c|}{$50.02 \%$} \\
\hline 4 & $\%$ with $\Delta F V_{\text {domestic }}^{F L O}>0$ & \multicolumn{2}{|c|}{$44.72 \%$} \\
\hline 5 & $\%$ with $\Delta F V^{F L O}>0$ & \multicolumn{2}{|c|}{$46.064 \%$} \\
\hline 6 & $\%$ with $\Delta F V_{\text {domestic }}^{L L O}>0$ & $45.332 \%$ & $45.688 \%$ \\
\hline 7 & $\%$ with $\Delta F V^{L L O}>0$ & $47.204 \%$ & $46.816 \%$ \\
\hline 8 & $\%$ with domestic investment & $0 \%$ & $53.312 \%$ \\
\hline 9 & $\%$ with domestic real investment & $0 \%$ & $0.128 \%$ \\
\hline 10 & $\varnothing \Delta F V$ & \multicolumn{2}{|c|}{$-1,393$} \\
\hline 11 & $\varnothing \Delta F V_{\text {domestic }}^{F L O}$ & \multicolumn{2}{|c|}{$-94,561$} \\
\hline 12 & $\varnothing \Delta F V^{F L O}$ & \multicolumn{2}{|c|}{$-73,578$} \\
\hline 13 & $\varnothing \Delta F V_{\text {domestic }}^{L L O}$ & $-193,502$ & $-206,933$ \\
\hline 14 & $\varnothing \Delta F V^{L L O}$ & $-150,338$ & $-138,901$ \\
\hline 15 & $\varnothing \Delta_{\text {domestic }}$ & 98,941 & 112,372 \\
\hline 16 & $\%$ with $\Delta_{\text {domestic }}<0$ & $54.864 \%$ & $55.664 \%$ \\
\hline 17 & $\varnothing \Delta$ & 76,759 & 65,323 \\
\hline 18 & $\%$ with $\Delta<0$ & $38.976 \%$ & $60.644 \%$ \\
\hline
\end{tabular}

As can be seen from line 8, the minimum tax induces a domestic lock-in effect that holds almost exclusively for financial investment. Domestic real investment is carried out rarely $(0,128 \%$ of all investment alternatives, see line 9$)$. Analyzing the intrastate and crossborder models reveals similar effects: The domestic minimum tax discriminates against real investment compared to neutral taxation. Compared to the case without minimum tax, the effects are contrary: The domestic minimum tax favors (discriminates against) real investment in the international (intrastate) case (lines 13 and 14). As a reflection, $\Delta$ is positive and decreases (rises) (lines 15 and 17). Loss offset paradox occur more frequently than without minimum tax in both cases (lines 16 and 18). The distribution of $\Delta$ becomes more skewed due to the minimum tax. 
Limiting the time of loss carryforwards induces the investment effects denoted in table 14:

Table 14: investment incentives from a time limit on loss carryforwards

\begin{tabular}{|c|c|c|c|}
\hline \multirow{2}{*}{$\begin{array}{l}1 \\
2\end{array}$} & \multicolumn{3}{|c|}{$L_{0}=500,000 ; \alpha=0 ; T_{f}=T$} \\
\hline & $T_{f}$ & $T$ & 5 \\
\hline 3 & $\%$ with $\Delta F V>0$ & & \\
\hline 4 & $\%$ with $\Delta F V_{\text {domestic }}^{F L O}>0$ & & \\
\hline 5 & $\%$ with $\Delta F V^{F L O}>0$ & & \\
\hline 6 & $\%$ with $\Delta F V_{\text {domestic }}^{L L O}>0$ & & \\
\hline 7 & $\%$ with $\Delta F V^{L L O}>0$ & $47.204 \%$ & $45.332 \%$ \\
\hline 8 & $\%$ with domestic investment & $0 \%$ & $82.372 \%$ \\
\hline 9 & $\%$ with domestic real investment & $0 \%$ & $27.704 \%$ \\
\hline 10 & $\varnothing \Delta F V$ & & \\
\hline 11 & $\varnothing \Delta F V_{\text {domestic }}^{F L O}$ & & \\
\hline 12 & $\varnothing \Delta F V^{F L O}$ & & \\
\hline 13 & $\varnothing \Delta F V_{\text {domestic }}^{L L O}$ & $-193,502$ & $-193,774$ \\
\hline 14 & $\varnothing \Delta F V^{L L O}$ & $-150,338$ & $-179,473$ \\
\hline 15 & $\varnothing \Delta_{\text {domestic }}$ & 98,941 & 99,214 \\
\hline 16 & $\%$ with $\Delta_{\text {domestic }}<0$ & $54.864 \%$ & $54.78 \%$ \\
\hline 17 & $\varnothing \Delta$ & 76,759 & 105,895 \\
\hline 18 & $\%$ with $\Delta<0$ & $38.976 \%$ & $17.7 \%$ \\
\hline
\end{tabular}

The domestic lock-in effect is even more pronounced than for a minimum tax. Now, a significant percentage of domestic real investment is carried out. Neglecting cross-country differences, real investment is discriminated against. The difference of FVs decreases in the intrastate as well as in the cross-border case and $\Delta$ increases whereas the number of loss offset paradox declines.

Varying foreign loss offset parameters is almost ineffective. This is true for a foreign minimum tax as well as a time limit on foreign loss carryforwards. Therefore, the associated values are left aside.

Dropping the assumption of expected marginal investment and assuming an expected pre-tax rate of return of $20 \%$ - this corresponds to a starting value of $C F_{0}=624.776$ enhances the relative importance of the nominal tax rate compared to loss offset rules. The choice of location mainly follows the nominal tax rate. As a consequence, no single domestic real investment project out of 25,000 cases is carried out, neither with nor without minimum tax. A lock-in effect does not exist for expected infra-marginal investment projects, as can be seen from table 15 : 
Table 15: investment incentives of a domestic minimum tax

\begin{tabular}{|c|c|c|c|c|c|}
\hline 1 & $C F_{0}$ & \multicolumn{4}{|c|}{$\begin{array}{c}T_{f}=T_{f}^{*}=T \\
624,776\end{array}$} \\
\hline 2 & $\alpha$ & 0 & 0 & 0,4 & 0,4 \\
\hline & $L_{0}$ & 0 & 500,000 & 0 & 500,000 \\
\hline 3 & $\%$ with $\Delta F V>0$ & \multicolumn{4}{|c|}{$99.464 \%$} \\
\hline 4 & $\%$ with $\Delta F V_{\text {domestic }}^{F L O}>0$ & \multicolumn{4}{|c|}{$98.968 \%$} \\
\hline 5 & $\%$ with $\Delta F V^{F L O}>0$ & $99.156 \%$ & $99.152 \%$ & $99.156 \%$ & $99.152 \%$ \\
\hline 6 & $\%$ with $\Delta F V_{\text {domestic }}^{L L O}>0$ & $98.608 \%$ & $98.824 \%$ & $98.608 \%$ & $98.864 \%$ \\
\hline 7 & $\%$ with $\Delta F V^{L L O}>0$ & $99.096 \%$ & $99.168 \%$ & $99.096 \%$ & $99.16 \%$ \\
\hline 8 & $\%$ domestic investment & \multicolumn{3}{|c|}{$0 \%$} & $0,84 \%$ \\
\hline 9 & $\%$ domestic 1 & \multicolumn{4}{|c|}{$0 \%$} \\
\hline 10 & $\varnothing \Delta F V$ & \multicolumn{4}{|c|}{$3,596,601$} \\
\hline 11 & $\varnothing \Delta F V_{d o m}^{F L}$ & \multicolumn{4}{|c|}{$1,690,838$} \\
\hline 12 & $\varnothing \Delta F V^{F L}$ & $2,097,433$ & \multicolumn{3}{|c|}{$2,097,327$} \\
\hline 13 & $\varnothing \Delta F V_{\text {domest }}^{L L O}$ & $1,687,139$ & $1,719,695$ & $1,687,139$ & $1,733,926$ \\
\hline 14 & $\varnothing \Delta F V^{L L O}$ & $2,096,438$ & $2,037,187$ & $2,096,438$ & $2,088,674$ \\
\hline 15 & $\varnothing \Delta_{\text {domesti }}$ & 3,699 & $-28,857$ & 3,699 & $-43,088$ \\
\hline 16 & $\%$ with $\Delta_{\text {domestic }}<0$ & $0 \%$ & $97.932 \%$ & $0 \%$ & $98.376 \%$ \\
\hline 17 & $\varnothing \Delta$ & 995 & 60,139 & 995 & 8,652 \\
\hline 18 & $\%$ with $\Delta<0$ & $0 \%$ & $9.628 \%$ & $0 \%$ & $43.652 \%$ \\
\hline
\end{tabular}

Introducing an initial loss carryforward substantially changes the optimal investment alternatives. Without initial loss carryforward, the foreign branch is the optimal alternative, with a sufficiently large initial loss carryforward, it is the foreign subsidiary. For $L_{0}=500,000 ; \alpha=0$, real investment is carried out in the foreign subsidiary in 24,434 cases (foreign branch: 358 cases), for $L_{0}=0$, only in 442 cases (foreign branch: 24,332 cases). The reason is that investment in a foreign subsidiary enables to use domestic loss carryforwards - at least to a limited degree. Although this advantage declines after the introduction of a minimum tax, the foreign subsidiary remains the optimal alternative in this case. Introducing a minimum tax reduces the arithmetic mean of $\Delta$ which means that discrimination of real investment compared to financial investment is reduced. In the parameter setting considered here, the minimum tax induces only secondary investment incentives. This is also true for a time limit on loss carryforwards.

\subsection{Increasing cash flows}

Cash flows that expectedly increase over time will be modeled by $\mu=+100,000$. Expected marginal investment is associated with a starting value $C F_{0}=-309,801$, infra-marginal investment with an expected rate of return of $20 \%$ with a starting value $C F_{0}=-84,043$.

On average, the present value of linear depreciation allowances exceeds the present value of economic depreciation. Thus, under taxation with full loss offset, the percentage of 
projects with a positive difference of FVs increases compared to the pre-tax case (lines $3-5)$.

For expected marginal projects, a domestic lock-in effect can be observed only for relatively large values of the initial loss carryforward. If such a lock-in effect occurs, it applies almost exclusively for financial investment. For $L_{0}=750,000$, domestic real investment is the optimal alternative in less than $1 \%$ of cases (line 9 of table 16). Typically, the optimal alternative is the foreign subsidiary.

An increasing initial loss offset tends to discriminate against real investment, even in the absence of special loss offset restrictions (line 17 of table 16). The mean difference of FVs becomes negative in the intrastate as well as in the cross-border setting. A loss offset paradox can be observed in no single out of 25,000 cases.

Table 16: investment effects of initial loss carryforwards

\begin{tabular}{|c|c|c|c|c|c|}
\hline 1 & $C F_{0}$ & \multicolumn{4}{|c|}{$\begin{array}{c}\alpha=0 ; T_{f}=T_{f}^{*}=T \\
-309,801\end{array}$} \\
\hline 2 & $L_{0}$ & 0 & 250,000 & 500,000 & 750,000 \\
\hline 3 & $\%$ with $\Delta F V>0$ & \multicolumn{4}{|c|}{$50.02 \%$} \\
\hline 4 & $\%$ with $\Delta F V_{\text {domestic }}^{F L O}>0$ & \multicolumn{4}{|c|}{$63.984 \%$} \\
\hline 5 & $\%$ with $\Delta F V^{F L O}>0$ & \multicolumn{4}{|c|}{$60.692 \%$} \\
\hline 6 & $\%$ with $\Delta F V_{\text {domestic }}^{L L O}>0$ & $57.232 \%$ & $54.62 \%$ & $52.744 \%$ & $51.432 \%$ \\
\hline 7 & $\%$ with $\Delta F V^{L L O}>0$ & $55.54 \%$ & $53.82 \%$ & $53.82 \%$ & $51.432 \%$ \\
\hline 8 & $\%$ domestic investment & \multicolumn{3}{|c|}{$0 \%$} & $49.5 \%$ \\
\hline 9 & $\%$ domestic real investment & \multicolumn{3}{|c|}{$0 \%$} & $0.932 \%$ \\
\hline 10 & $\varnothing \Delta F V$ & \multicolumn{4}{|c|}{$-1,393$} \\
\hline 11 & $\varnothing \Delta F V_{\text {domestic }}^{F L O}$ & \multicolumn{4}{|c|}{257,224} \\
\hline 12 & $\varnothing \Delta F V^{F L O}$ & 246,987 & 244,369 & 242,187 & 240,408 \\
\hline 13 & $\varnothing \Delta F V_{\text {domest }}^{L L O}$ & 82,557 & 17,061 & $-37,184$ & $-84,771$ \\
\hline 14 & $\varnothing \Delta F V^{L L O}$ & 80,159 & 35,957 & $-5,657$ & $-37,293$ \\
\hline 15 & $\varnothing \Delta_{\text {domestic }}$ & 174,667 & 240,163 & 294,408 & 341,995 \\
\hline 16 & $\%$ with $\Delta_{\text {domestic }}<0$ & \multicolumn{4}{|c|}{$0 \%$} \\
\hline 17 & $\varnothing \Delta$ & 166,828 & 208,411 & 247,844 & 277,701 \\
\hline 18 & $\%$ with $\Delta<0$ & \multicolumn{4}{|c|}{ - } \\
\hline
\end{tabular}

As can be seen in table 17, a domestic minimum tax causes a domestic lock-in effect which exclusively applies to financial investment. In no single case out of 25,000, domestic real investment is the optimal investment alternative for $L_{0}=500,000$ and $\alpha=0.4$. Comparing lines 13 and 14 reveals that the investment effects of introducing a minimum tax can differ from an intrastate and a cross-border perspective. In an intrastate setting, a domestic minimum tax increases (line 13), in an international setting, a domestic minimum tax surprisingly reduces the discrimination of real investment (line 14). All in all, a significant relative disadvantage for real investment remains $(\Delta>0$, lines 15 and 17). 
Table 17: investment incentives of a domestic minimum tax

\begin{tabular}{|c|c|c|c|}
\hline & \multicolumn{3}{|c|}{$L_{0}=500,000 ; T_{f}=T_{f}^{*}=T$} \\
\hline 1 & $C F_{0}$ & \multicolumn{2}{|c|}{$-309,801$} \\
\hline 2 & $\alpha$ & 0 & 0,4 \\
\hline 3 & $\%$ with $\Delta F V>0$ & \multicolumn{2}{|c|}{$50.02 \%$} \\
\hline 4 & $\%$ with $\Delta F V_{\text {domestic }}^{F L O}>0$ & \multicolumn{2}{|c|}{$63.984 \%$} \\
\hline 5 & $\%$ with $\Delta F V^{F L O}>0$ & \multicolumn{2}{|c|}{$60.692 \%$} \\
\hline 6 & $\%$ with $\Delta F V_{\text {domestic }}^{L L O}>0$ & $52.744 \%$ & $52.312 \%$ \\
\hline 7 & $\%$ with $\Delta F V^{L L O}>0$ & $53.82 \%$ & $53.44 \%$ \\
\hline 8 & $\%$ domestic investment & $0 \%$ & $46.56 \%$ \\
\hline 9 & $\%$ domestic real investment & \multicolumn{2}{|c|}{$0 \%$} \\
\hline 10 & $\varnothing \Delta F V$ & \multicolumn{2}{|c|}{$-1,393$} \\
\hline 11 & $\varnothing \Delta F V_{\text {domestic }}^{F L O}$ & \multicolumn{2}{|c|}{257,224} \\
\hline 12 & $\varnothing \Delta F V^{F L O}$ & \multicolumn{2}{|c|}{242,187} \\
\hline 13 & $\varnothing \Delta F V_{\text {domestic }}^{L L O}$ & $-37,184$ & $-97,811$ \\
\hline 14 & $\varnothing \Delta F V^{L L O}$ & $-5,657$ & 14,476 \\
\hline 15 & $\varnothing \Delta_{\text {domestic }}$ & 294,408 & 355,035 \\
\hline 16 & $\%$ with $\Delta_{\text {domestic }}<0$ & \multicolumn{2}{|c|}{$0 \%$} \\
\hline 17 & $\varnothing \Delta$ & 247,844 & 227,711 \\
\hline 18 & $\%$ with $\Delta<0$ & \multicolumn{2}{|c|}{$0 \%$} \\
\hline
\end{tabular}

A time limit on loss carryforwards overwhelmingly discriminates real investment. For $L_{0}=500,000$, the mean difference of FVs is negative (table 18, lines 13 and 14), and the $\Delta$-values increase substantially. The domestic lock-in effect only applies to financial investment (lines 8 and 9). 
Table 18: investment incentives from a time limit on loss carryforwards

\begin{tabular}{|c|c|c|c|c|}
\hline 1 & $C F_{0}$ & \multicolumn{3}{|c|}{$\begin{array}{c}L_{0}=500,000 ; \alpha=0 ; T_{f}^{*}=T \\
-309,801\end{array}$} \\
\hline 2 & $T_{f}$ & $T$ & & 5 \\
\hline 3 & $\%$ with $\Delta F V>0$ & & $50.02 \%$ & \\
\hline 4 & $\%$ with $\Delta F V_{\text {domestic }}^{F L O}>0$ & & $63.984 \%$ & \\
\hline 5 & $\%$ with $\Delta F V^{F L O}>0$ & & $60.692 \%$ & \\
\hline 6 & $\%$ with $\Delta F V_{\text {domestic }}^{L L O}>0$ & $52.744 \%$ & & $41.548 \%$ \\
\hline 7 & $\%$ with $\Delta F V^{L L O}>0$ & $53.82 \%$ & & $49.888 \%$ \\
\hline 8 & $\%$ domestic investment & $0 \%$ & & $50.112 \%$ \\
\hline 9 & $\%$ domestic real investment & \multicolumn{3}{|c|}{$0 \%$} \\
\hline 10 & $\varnothing \Delta F V$ & \multicolumn{3}{|c|}{$-1,393$} \\
\hline 11 & $\varnothing \Delta F V_{\text {domestic }}^{F L O}$ & \multicolumn{3}{|c|}{257,224} \\
\hline 12 & $\varnothing \Delta F V^{F L O}$ & \multicolumn{3}{|c|}{242,187} \\
\hline 13 & $\varnothing \Delta F V_{\text {domestic }}^{L L O}$ & $-37,184$ & & $-235,092$ \\
\hline 14 & $\varnothing \Delta F V^{L L O}$ & $-5,657$ & & $-48,760$ \\
\hline 15 & $\varnothing \Delta_{\text {domestic }}$ & 294,408 & & 492,316 \\
\hline 16 & $\%$ with $\Delta_{\text {domestic }}<0$ & \multicolumn{3}{|c|}{$0 \%$} \\
\hline 17 & $\varnothing \Delta$ & 247,844 & & 290,947 \\
\hline 18 & $\%$ with $\Delta<0$ & \multicolumn{3}{|c|}{$0 \%$} \\
\hline
\end{tabular}

Restricting foreign loss offset parameters slightly increases the domestic lock-in effect that occurs for $L_{0}=500,000$ und $\alpha=0.4$. Since only foreign investment is discriminated against in this setting, the attractiveness of real investment that is exclusively realized in the foreign country, is reduced, too. For $T_{f}^{*}=5$, the mean difference of FVs becomes negative. A foreign minimum tax $\left(\alpha^{*}=0.5\right)$ does not induce a domestic lock-in effect and does not cause noticeable investment effects.

For expected infra-marginal projects $\left(C F_{0}=-84,043\right)$ with increasing cash flows, an initial loss carryforward typically discriminates against real investment (table 19, lines 14 and 17), because loss carryforwards can be offset against profits later than for financial investment. 
Table 19: investment effects of loss offset restrictions

\begin{tabular}{|c|c|c|c|c|c|}
\hline 1 & $C F_{0}$ & \multicolumn{4}{|c|}{$-84,043$} \\
\hline 2 & $L_{0}$ & 0 & 500,000 & 500,000 & 500,000 \\
\hline & $\alpha$ & 0 & 0 & 0 & 0,4 \\
\hline & $T_{f}$ & $T$ & $T$ & 5 & $T$ \\
\hline & $T_{f}^{*}$ & $T$ & $T$ & $T$ & $T$ \\
\hline 3 & $\%$ with $\Delta F V>0$ & \multicolumn{4}{|c|}{$99.464 \%$} \\
\hline 4 & $\%$ with $\Delta F V_{\text {domestic }}^{F L O}>0$ & \multicolumn{4}{|c|}{$99.76 \%$} \\
\hline 5 & $\%$ with $\Delta F V^{F L O}>0$ & \multicolumn{4}{|c|}{$99.696 \%$} \\
\hline 6 & $\%$ with $\Delta F V_{\text {domestic }}^{L L O}>0$ & $99.668 \%$ & $99.556 \%$ & $99.112 \%$ & $99.556 \%$ \\
\hline 7 & $\%$ with $\Delta F V^{L L O}>0$ & $99.628 \%$ & $99.576 \%$ & $99.444 \%$ & $99.564 \%$ \\
\hline 8 & $\%$ domestic investment & \multicolumn{2}{|c|}{$0 \%$} & $0.56 \%$ & $0.436 \%$ \\
\hline 9 & $\%$ domestic real investment & 0 & & $0.004 \%$ & $0 \%$ \\
\hline 10 & $\varnothing \Delta F V$ & \multicolumn{4}{|c|}{$3,596,601$} \\
\hline 11 & $\varnothing \Delta F V_{\text {domestic }}^{F L O}$ & \multicolumn{4}{|c|}{$2,042,622$} \\
\hline 12 & $\varnothing \Delta F V^{F L O}$ & $2,417,231$ & \multicolumn{3}{|c|}{$2,417,223$} \\
\hline 13 & $\varnothing \Delta F V_{\text {domestic }}^{L L O}$ & $2,033,091$ & $2,005,945$ & $1,988,247$ & $2,015,305$ \\
\hline 14 & $\varnothing \Delta F V^{L L O}$ & $2,408,333$ & $2,261,634$ & $2,279,414$ & $2,313,493$ \\
\hline 15 & $\varnothing \Delta_{\text {domestic }}$ & 9,531 & 36,677 & 54,376 & 27,318 \\
\hline 16 & $\%$ with $\Delta_{\text {domestic }}<0$ & $0 \%$ & \multicolumn{2}{|c|}{$2.292 \%$} & $13.924 \%$ \\
\hline 17 & $\varnothing \Delta$ & 8,898 & 155,589 & 137,809 & 103,730 \\
\hline 18 & $\%$ with $\Delta<0$ & \multicolumn{4}{|c|}{$0 \%$} \\
\hline
\end{tabular}

Introducing a minimum tax can reduce the discrimination of real investment in the intrastate as well as in the cross-border setting. This effect can be seen from the reduced values of $\Delta$, which are still positive. A significant domestic lock-in effect does not occur, neither for the minimum tax nor for a time limit on loss carryforwards. The latter restriction provokes almost no effects for $L_{0}=0$ and induces a slightly reduced discrimination of real investment for $L_{0}=500,000$. A loss offset paradox could not be observed for these parameters. Even in an intrastate setting, seemingly paradox effects are rare. Again, restrictions on foreign loss offset parameters do not induce noticeable investment effects.

\subsection{Results}

The Monte Carlo simulations confirm the results from the deterministic examples. A summarizing overview of the investment incentives reveals the following:

- Varying a single loss offset parameter typically induces ambiguous effects. Investment incentives are almost always combinations of all parameters under consideration.

- The results are especially sensitive with respect to the initial loss carryforward.

- On average, financial investment is favored over real investment for all structures of cash flows and all versions of incomplete loss offset. However, it is easy to find single counter-examples. 
- Investment projects with decreasing cash flows are less likely to be discriminated against than projects with increasing cash flows.

- Expected infra-marginal projects are less likely to be discriminated against than expected marginal projects.

- A domestic minimum tax tends to reduce the discrimination of real investment slightly.

- A time limit on domestic loss carryforwards intensifies the discrimination of real investment.

- A loss offset paradox occurs less frequently in an international setting than in an intrastate setting. From an intrastate perspective, negative values for $\Delta$ could be observed mainly for expected marginal projects with decreasing cash flows. In contrast to the intrastate case, the arithmetic mean of $\Delta$ was always positive in the cross-border setting.

- An initial domestic loss carryforward generates a domestic lock-in effect.

- Domestic loss offset limitations may intensify the domestic lock-in effect. Depending on the parameter setting, the opposite - a push-out effect - may occur as well.

- Foreign loss offset limitations were largely ineffective.

\section{Summary and conclusion}

This paper analyzes the investment incentives of loss offset restrictions for investors with cross-border activities. Since both real and financial investment can be carried out domestically as well as abroad, it is necessary to determine the optimal way for both alternatives. To put a limit on the variety of possible legal structures, the analysis is restricted to the alternatives "domestic business", "foreign branch", and "foreign subsidiary". The optimization process is simplified by the assumption of irreversible investment which implies that only terminal repatriation is possible. The alternatives with the maximum FV have to be computed. By comparing both optimal alternatives, it can be decided whether or not to invest and which alternative to choose. Thus, investment effects of loss offset restrictions have to be identified by the relative impact on real versus financial investment.

A prominent loss offset parameter is an initial domestic loss carryforward. Integrating a loss carryforward at the time of investment creates a decision situation neglected by the literature until now. The other parameters under consideration are a minimum tax on positive profits regardless of existing loss carryforwards and a time limit on loss carryforwards. It is necessary to distinguish between different cash flow structures and different rates of return, because investment incentives are ambiguous.

A sufficiently high initial loss carryforward creates a domestic lock-in effect. This effect is highly relevant for financial investment, but occurs rarely for real investment. The 
lock-in effect may be strengthened by domestic loss offset restrictions, but the opposite is possible, too.

Whereas the incentives of a minimum tax are ambiguous - it may favor as well as discriminate against real investment - a time limit on loss carryforwards mostly discriminates against real investment projects. Foreign loss offset restrictions are largely irrelevant for investment decisions.

The example of loss offset rules clarifies the necessity of international tax planning for investors as well as fiscal authorities. As could be shown, even small variations of loss offset parameters may be sufficient to turn a lock-in effect into a push-out effect. Therefore, it is sensible from a fiscal perspective to anticipate the tax revenue effects of particular tax law settings by using investor-oriented models. At the moment, there is no evidence that this actually happens.

Tax planning of cross-border investment further offers insights into taxational choices. Although the choice of location is no taxational choice in the first place, it offers the investor the possibility to influence his own tax burden. Hence, it is an actual taxational choice. As long as taxational choices exist, tax neutrality is impossible from an intrastate as well as a cross-border perspective. This is an unsolved problem, not only for public economists who are in favor of tax neutrality, but also for tax planners who need a yardstick for measuring tax effects. In our analysis, complete loss offset was the appropriate yardstick for an isolated analysis of loss offset limitations. Tax neutrality is defined only for the tax base as a whole, not for particular tax base elements. Since different tax base elements may induce offsetting investment incentives, normative statements on the desirability of particular loss offset limitations are impossible from the perspective of tax neutrality. 


\section{References}

Altfelder, Stefan (2000): Mindestbesteuerung - Chaos mit System?, in: Finanz-Rundschau $82,18-43$.

Altshuler, Rosanne / Auerbach, Alan J. (1990): The Significance of Tax Law Asymmetries: An Empirical Investigation, in: Quarterly Journal of Economics 105, 61-89.

Altshuler, Rosanne / Grubert, Harry (2002): Repatriation Taxes, Repatriation Strategies and Multinational Financial Policy, in: Journal of Public Economics 87, 73-107.

Altshuler, Rosanne / Newlon, T. Scott (1993): The Effects of U.S. Tax Policy on the Income Repatriation Patterns of U.S. Multinational Corporations, in: Giovannini, Alberto / Hubbard, R. Glenn / Slemrod, Joel (ed.): Studies in International Taxation, Chicago, 77-115.

Alworth, Julian (1988): The Finance, Investment and Taxation Decisions of Multinationals, Oxford, New York.

Auerbach, Alan J. (1986): The Dynamic Effects of Tax Law Asymmetries, in: Review of Economic Studies 53, 205-225.

Auerbach, Alan J. / Poterba, James M. (1987): Tax Loss Carryforwards and Corporate Tax Incentives, in: Feldstein, Martin (ed.): The Effects of Taxation on Capital Accumulation, Chicago, 305-338.

Babcock, Jennifer (2000): The Effects of Imputation Systems on Multinational Investment, Financing, and Income-Shifting Strategies, in: Journal of the American Taxation Association 22, 1-21.

Ball, Ray / Bowers, John (1982): Distortions Created by Taxes Which are Options on Value Creation: The Australian Resources Rent Tax Proposal 1982, in: Australian Journal of Management 8/2, 1-14.

Barlev, Benzion / Levy, Haim (1975): Loss Carryback and Carryover Provision: Effectiveness and Economic Implications, in: National Tax Journal 28, 173-184.

Bernheim, B. Douglas (1989): Incentive Effects of the Corporate Alternative Minimum Tax, in: Tax Policy and the Economy 3, 69-95.

Burman, Leonard E. / Gale, William G. / Rohaly, Jeffrey (2003): The Expanding Reach of the Individual Alternative Minimum Tax, in: Journal of Economic Perspectives $17,173-186$.

Burman, Leonard E. / Gale, William G. / Rohaly, Jeffrey (2002): The Individual AMT: Problems and Potential Solutions, in: National Tax Journal 55, 555-596.

Cooper, Ian / Franks, Julian R. (1983): The Interaction of Financing and Investment Decisions When the Firm has Unused Tax Credits, in: Journal of Finance, Papers \& Proceedings 38, 571-583. 
De Waegenaere, Anja / Sansing, Richard / Wielhouwer, Jacco L. (2001): Valuation of Deferred Tax Assets from a Net Operating Loss Carryover, CentER Working Paper No. 2001-24.

Domar, Evsey D. / Musgrave, Richard A. (1944): Proportional Income Taxation and Risk-Taking, in: Quarterly Journal of Economics 56, 388-422.

Eeckhoudt, Louis / Gollier, Christian / Schlesinger, Harris (1997): The no-loss offset provision and the attitude towards risk of a risk-neutral firm, in: Journal of Public Economics 65, 207-217.

Eeckhoudt, Louis / Hansen, Pierre (1982): Uncertainty and the Partial Loss Offset Provision, in: Economics Letters 9, 31-35.

EU commission (ed.) (2001): Company Taxation in the Internal Market, Brussels.

Feenberg, Daniel / Poterba, James (2003): The Alternative Minimum Tax and Effective Marginal Tax Rates, NBER Working Paper No. 10072.

Gérard, Marcel / Weiner, Joann M. (2003): Cross-Border Loss Offset and Formulary Apportionment: How do they Affect Multijurisdictional Firm Investment Spending and Interjurisdictional Tax Competition? CESifo Working Paper No. 1004, Munich.

Gordon, Roger H. / Jun, Joosung (1993): Taxes and the Form of Ownership of Foreign Corporate Equity, in: Giovannini, Alberto / Hubbard, R. Glenn / Slemrod, Joel (ed.): Studies in International Taxation, Chicago, 13-44.

Grubert, Harry (1998): Taxes and the Division of Foreign Operating Income among Royalties, Interest, Dividends and Retained Earnings, in: Journal of Public Economics 68, 269-290.

Haegert, Lutz / Kramm, Rainer (1977): Die Bedeutung des steuerlichen Verlustrücktrags für die Rentabilität und das Risiko von Investitionen, in: Zeitschrift für betriebswirtschaftliche Forschung 29, 203-210.

Hartman, David G. (1985): Tax Policy and Foreign Direct Investment, in: Journal of Public Economics 26, 107-121.

Kari, Seppo / Ylä-Liedenpohja, Jouko (2003): Taxation and Valuation of International Real Investments, CESifo Working Paper No. 1013, Munich.

Leechor, Chad / Mintz, Jack (1993): On the taxation of multinational corporate investment when the deferral method is used by the capital exporting country, in: Journal of Public Economics 51, 75-96.

Lund, Diderik (2000): Imperfect loss offset and the after-tax expected rate of return to equity, with an application to rent taxation, Memorandum No. 21/2000, Department of Economics, University of Oslo. 
Lund, Diderik (1992): Petroleum Taxation under Uncertainty: Contingent Claims Analysis with an Application to Norway, in: Energy Economics 14, 23-31.

Lyon, Andrew B. (1997): Cracking the Code - Making Sense of the Corporate Alternative Minimum Tax, Washington D.C.

Lyon, Andrew B. (1990): Investment Incentives under the Alternative Minimum Tax, in: National Tax Journal 43, 451-465.

Lyon, Andrew B. / Silverstein, Gerald (1995): The Alternative Minimum Tax and the Behavior of Multinational Corporations, in: Feldstein, Martin (ed.): The Effects of Taxation on Multinational Corporations, Chicago, 153-177.

MacKie-Mason, Jeffrey K. (1990): Some Nonlinear Tax Effects on Asset Values and Investment Decisions under Uncertainty, in: Journal of Public Economics 42, 301327.

Majd, Saman / Myers, Stewart C. (1987): Tax Asymmetries and Corporate Income Tax Reform, in: Feldstein, Martin (ed.): The Effects of Taxation on Capital Accumulation, Chicago, 343-373.

Majd, Saman / Myers, Stewart C. (1985): Valuing the Government's Tax Claim on Risky Corporate Assets, NBER Working Paper No. 1553.

Mintz, Jack (1988): An Empirical Estimate of Corporate Tax Refundability and Effective Tax Rates, in: Quarterly Journal of Economics 103, 225-231.

Niemann, Rainer (2003): Wie schädlich ist die Mindestbesteuerung? - Steuerparadoxa in der Verlustverrechnung, Tübinger Diskussionsbeitrag Nr. 259, Wirtschaftswissenschaftliche Fakultät, Universität Tübingen.

Raupach, Arndt / Böckstiegel, Martin (1999): Die Verlustregelungen des Steuerentlastungsgesetzes 1999/2000/2002, in: Finanz-Rundschau 81, 487-503; 557-573; 617628.

Schnabel, Jacques A. / Roumi, Ebrahim A. (1990): Contingent Claims Analysis of Partial Loss Offset Taxation and Risk-Taking, in: Public Finance 45, 304-320.

Scholes, Myron S. / Wolfson, Mark A. / Erickson, Merle E. / Maydew, Edward L. / Shevlin, Terry J.(2001): Taxes and Business Strategy - A Planning Approach, 2nd ed., Upper Saddle River.

Schneider, Dieter (1992): Investition, Finanzierung und Besteuerung, 7th ed., Wiesbaden.

Shevlin, Terry (1990): Estimating Corporate Marginal Tax Rates with Asymmetric Tax Treatment of Gains and Losses, in: Journal of the American Taxation Association $12,51-67$. 
Sinn, Hans-Werner (1993): Taxation and the Birth of Foreign Subsidiaries, in: Herberg, Horst (ed.): Trade, Welfare and Economic Policies: Essays in Honor of Murray C. Kemp, Ann Arbor, 325-352.

Wagner, Franz W. / Dirrigl, Hans (1980): Die Steuerplanung der Unternehmung, Stuttgart.

Weichenrieder, Alfons J. (1996): Anti-Tax-Avoidance Provisions and the Size of Foreign Direct Investment, in: International Tax and Public Finance 3, 67-81.

Wunder, Haroldene F. (1999): International Tax Reform: Its Effect on Repatriation Decisions of Multinational Corporations, in: Journal of International Accounting, Auditing \& Taxation 8, 337-353. 


\section{CESifo Working Paper Series}

(for full list see www.cesifo.de)

1153 Wolfgang Ochel, Welfare-to-Work Experiences with Specific Work-First Programmes in Selected Countries, March 2004

1154 Jan K. Brueckner and Eric Pels, European Airline Mergers, Alliance Consolidation, and Consumer Welfare, March 2004

1155 Aaron Tornell, Frank Westermann, and Lorenza Martínez, NAFTA and Mexico's Economic Performance, March 2004

1156 George Economides, Sarantis Kalyvitis, and Apostolis Philippopoulos, Do Foreign Aid Transfers Distort Incentives and Hurt Growth? Theory and Evidence from 75 Aidrecipient Countries, March 2004

1157 Robert Fenge and Volker Meier, Are Family Allowances and Fertility-related pensions Siamese Twins?, March 2004

1158 Bruno S. Frey, Simon Luechinger, and Alois Stutzer, Valuing Public Goods: The Life Satisfation Approach, March 2004

1159 Jerome L. Stein and Guay C. Lim, Asian Crises: Theory, Evidence, Warning-Signals, March 2004

1160 Romain Ranciere, Aaron Tornell, and Frank Westermann, Crises and Growth: A ReEvaluation, March 2004

1161 Assaf Razin and Efraim Sadka, Transparency, Specialization and FDI, March 2004

1162 Ludger Woessmann, How Equal Are Educational Opportunities? Family Background and Student Achievement in Europe and the United States, March 2004

1163 B.M.S. van Praag and Barbara E. Baarsma, Using Happiness Surveys to Value Intangibles: The Case of Airport Noise, March 2004

1164 Aaron Tornell, Frank Westermann, and Lorenza Martínez, The Positive Link Between Financial Liberalization, Growth, and Crises, March 2004

1165 Helge Berger and Carsten Hefeker, One Country, One Vote? Labor Market Structure and Voting Rights in the ECB, March 2004

1166 Clemens Fuest and Martin Kolmar, A Theory of User-Fee Competition, March 2004

1167 Friedrich Schneider and Robert Klinglmair, Shadow Economies around the World: What Do We Know?, April 2004 
1168 Horst Raff and Nicolas Schmitt, Exclusive Dealing and Common Agency in International Markets, April 2004

1169 M. Hashem Pesaran and Allan Timmermann, Real Time Econometrics, April 2004

1170 Sean D. Barrett, Privatisation in Ireland, April 2004

1171 V. Anton Muscatelli, Patrizio Tirelli and Carmine Trecroci, Can Fiscal Policy Help Macroeconomic Stabilisation? Evidence from a New Keynesian Model with Liquidity Constraints, April 2004

1172 Bernd Huber and Marco Runkel, Tax Competition, Excludable Public Goods and User Charges, April 2004

1173 John McMillan and Pablo Zoido, How to Subvert Democracy: Montesinos in Peru, April 2004

1174 Theo Eicher and Jong Woo Kang, Trade, Foreign Direct Investment or Acquisition: Optimal Entry Modes for Multinationals, April 2004

1175 Chang Woon Nam and Doina Maria Radulescu, Types of Tax Concessions for Attracting Foreign Direct Investment in Free Economic Zones, April 2004

1176 M. Hashem Pesaran and Andreas Pick, Econometric Issues in the Analysis of Contagion, April 2004

1177 Steinar Holden and Fredrik Wulfsberg, Downward Nominal Wage Rigidity in Europe, April 2004

1178 Stefan Lachenmaier and Ludger Woessmann, Does Innovation Cause Exports? Evidence from Exogenous Innovation Impulses and Obstacles, April 2004

1179 Thiess Buettner and Johannes Rincke, Labor Market Effects of Economic Integration The Impact of Re-Unification in German Border Regions, April 2004

1180 Marko Koethenbuerger, Leviathans, Federal Transfers, and the Cartelization Hypothesis, April 2004

1181 Michael Hoel, Tor Iversen, Tore Nilssen, and Jon Vislie, Genetic Testing and Repulsion from Chance, April 2004

1182 Paul De Grauwe and Gunther Schnabl, Exchange Rate Regimes and Macroeconomic Stability in Central and Eastern Europe, April 2004

1183 Arjan M. Lejour and Ruud A. de Mooij, Turkish Delight - Does Turkey’s accession to the EU bring economic benefits?, May 2004

1184 Anzelika Zaiceva, Implications of EU Accession for International Migration: An Assessment of Potential Migration Pressure, May 2004 
1185 Udo Kreickemeier, Fair Wages and Human Capital Accumulation in a Global Economy, May 2004

1186 Jean-Pierre Ponssard, Rent Dissipation in Repeated Entry Games: Some New Results, May 2004

1187 Pablo Arocena, Privatisation Policy in Spain: Stuck Between Liberalisation and the Protection of Nationals' Interests, May 2004

1188 Günter Knieps, Privatisation of Network Industries in Germany: A Disaggregated Approach, May 2004

1189 Robert J. Gary-Bobo and Alain Trannoy, Efficient Tuition Fees, Examinations, and Subsidies, May 2004

1190 Saku Aura and Gregory D. Hess, What's in a Name?, May 2004

1191 Sjur Didrik Flåm and Yuri Ermoliev, Investment Uncertainty, and Production Games, May 2004

1192 Yin-Wong Cheung and Jude Yuen, The Suitability of a Greater China Currency Union, May 2004

1193 Inés Macho-Stadler and David Pérez-Castrillo, Optimal Enforcement Policy and Firms' Emissions and Compliance with Environmental Taxes, May 2004

1194 Paul De Grauwe and Marianna Grimaldi, Bubbles and Crashes in a Behavioural Finance Model, May 2004

1195 Michel Berne and Gérard Pogorel, Privatization Experiences in France, May 2004

1196 Andrea Galeotti and José Luis Moraga-González, A Model of Strategic Targeted Advertising, May 2004

1197 Hans Gersbach and Hans Haller, When Inefficiency Begets Efficiency, May 2004

1198 Saku Aura, Estate and Capital Gains Taxation: Efficiency and Political Economy Consideration, May 2004

1199 Sandra Waller and Jakob de Haan, Credibility and Transparency of Central Banks: New Results Based on Ifo's World Economicy Survey, May 2004

1200 Henk C. Kranendonk, Jan Bonenkamp, and Johan P. Verbruggen, A Leading Indicator for the Dutch Economy - Methodological and Empirical Revision of the CPB System, May 2004

1201 Michael Ehrmann, Firm Size and Monetary Policy Transmission - Evidence from German Business Survey Data, May 2004

1202 Thomas A. Knetsch, Evaluating the German Inventory Cycle - Using Data from the Ifo Business Survey, May 2004 
1203 Stefan Mittnik and Peter Zadrozny, Forecasting Quarterly German GDP at Monthly Intervals Using Monthly IFO Business Conditions Data, May 2004

1204 Elmer Sterken, The Role of the IFO Business Climate Indicator and Asset Prices in German Monetary Policy, May 2004

1205 Jan Jacobs and Jan-Egbert Sturm, Do Ifo Indicators Help Explain Revisions in German Industrial Production?, May 2004

1206 Ulrich Woitek, Real Wages and Business Cycle Asymmetries, May 2004

1207 Burkhard Heer and Alfred Maußner, Computation of Business Cycle Models: A Comparison of Numerical Methods, June 2004

1208 Costas Hadjiyiannis, Panos Hatzipanayotou, and Michael S. Michael, Pollution and Capital Tax Competition within a Regional Block, June 2004

1209 Stephan Klasen and Thorsten Nestmann, Population, Population Density, and Technological Change, June 2004

1210 Wolfgang Ochel, Welfare Time Limits in the United States - Experiences with a New Welfare-to-Work Approach, June 2004

1211 Luis H. R. Alvarez and Erkki Koskela, Taxation and Rotation Age under Stochastic Forest Stand Value, June 2004

1212 Bernard M. S. van Praag, The Connexion Between Old and New Approaches to Financial Satisfaction, June 2004

1213 Hendrik Hakenes and Martin Peitz, Selling Reputation When Going out of Business, June 2004

1214 Heikki Oksanen, Public Pensions in the National Accounts and Public Finance Targets, June 2004

1215 Ernst Fehr, Alexander Klein, and Klaus M. Schmidt, Contracts, Fairness, and Incentives, June 2004

1216 Amihai Glazer, Vesa Kanniainen, and Panu Poutvaara, Initial Luck, Status-Seeking and Snowballs Lead to Corporate Success and Failure, June 2004

1217 Bum J. Kim and Harris Schlesinger, Adverse Selection in an Insurance Market with Government-Guaranteed Subsistence Levels, June 2004

1218 Armin Falk, Charitable Giving as a Gift Exchange - Evidence from a Field Experiment, June 2004

1219 Rainer Niemann, Asymmetric Taxation and Cross-Border Investment Decisions, June 2004 